\title{
Islamic Banks and Monetary Policy: The Case of Indonesia
}

\author{
Regi Muzio Ponziani \\ STIE Trisakti, Indonesia, regi@stietrisakti.ac.id
}

Tatik Mariyanti

Universitas Trisakti, Indonesia, tatik_m2002@yahoo,com

\begin{abstract}
Article History
Received: September 17, 2019 Revised: January 26, 2020 Accepted: January 28, 2020
\end{abstract}

\begin{abstract}
Islamic banks in Indonesia exist side by side with their conventional counterparts within a dual banking system. The central bank aims to achieve price stability in the economy using both conventional and Islamic monetary instruments within this dual monetary system. This creates a unique environment for Islamic banks. This research aims to examine the role of Islamic banks in the monetary policy transmission mechanism using Granger Causality and Autoregressive Distributed Lag (ARDL). The balance sheet components of deposit and financing are hypothesized to function in the monetary transmission process within the bank financing channel. Granger causality reveals that the Islamic interbank overnight rate Granger causes Islamic deposits and financing, and that these in turn Granger cause the industrial production index. This index Granger causes inflation, Islamic deposits, and the Islamic interbank overnight rate. Islamic deposits and inflation then Granger cause the Islamic interbank overnight rate. The ARDL results show cointegrating relationships in the output and inflation model. Long-term convergence could be achieved to correct deviations in output and inflation by way of Islamic banks' deposits and financing. However, there is only a short-term influence of Islamic bank deposits on output. In the short-run, these deposits do not contribute to inflation. Islamic bank financing does not have a short-term relationship with output and inflation; therefore, there is declining effectiveness of Islamic banks' financing contribution to the economy.
\end{abstract}

Keywords: Monetary Policy Transmission Mechanism, ARDL, Granger Causality JEL Classification: C540; E52; E58; G20

@ IJIEF 2020 published by Universitas Muhammadiyah Yogyakarta, Indonesia All rights reserved

DOI:

https://doi.org/10.18196/ijief.2124
Web:

http://journal.umy.ac.id/index.php/ijief/article/view/7094

\section{Citation:}

Ponziani, R. M., \& Mariyanti, T. (2020). Islamic Banks and Monetary Policy: The Case of Indonesia. IJIEF: International Journal of Islamic Economics and Finance, 3(1). 121-142. DOI: https://doi.org/10.18196/ijief.2124 
Ponziani \& Mariyanti | Islamic Banks and Monetary Policy: The Case of Indonesia

\section{Introduction}

\subsection{Background}

Islamic economics promotes the concepts of trade and profit-and-loss sharing, or PLS (including risk sharing), as the main instruments that drive the economy. Based on these concepts, a certain level of risk has to be borne before assuming the right to returns. As opposed to the conventional framework, which is based mainly and solely on the concept of interest, justice and fairness are highly considered in economic activities in the Islamic system. With PLS and trading concepts, no oppression can be imposed on one side of the transaction. In the conventional purview, it is reasonable to expect a fixed return on capital loaned. This is because loans are considered equal to the rent of money. One has foregone his right to use the capital at the moment, so they need to be compensated in the form of a required fixed return. However, Islamic banking operates on the basis of Islamic values; transactions should be just and fair and in accordance with Islamic law. Supervisory boards oversee and monitor the transactions made by Islamic banks. Risk and return sharing products are among the main offers of such bank, together with trade products. What makes Islamic banks special is that financial stability is enhanced by the existence of risk sharing activities (Alaro \& Hakeem, 2011; Yungucu \& Saiti, 2016; Miah \& Uddin, 2017). Whenever there are shocks to the financial system, Islamic banks can absorb these and transmit them. Shocks will mostly affect the assets side of a bank's balance sheet. However, due to the risk sharing nature of Islamic banking, these shocks will be transmitted to the liabilities side. This capability will render Islamic banks capable of withstanding uncertainty in the economy (Rashid, Yousaf, \& Khaleequzzaman, 2017). This is opposed to the conventional system, in which banks will fully absorb shocks and see their assets and equity impacted. This will render the economy more vulnerable to crisis and can lead to systemic risk taking place in it. However, Islamic banks are also expected to perform certain functions undertaken by conventional banks; for example, they should facilitate payments and use the scale advantage to exploit opportunities in order to minimize market imperfection. For instance, Islamic banks, just like conventional ones, can ease the burden of information costs when they are about to grant financing to the public. Regulations imposed by central banks also apply to Islamic banks. Therefore, required capital and reserve requirements should be observed carefully. In addition, Bank Indonesia, as the central bank, has two monetary instruments at its disposal. It can employ both conventional and Islamic monetary instruments to transmit its monetary policy. Conventional monetary instruments make use of interest rates to influence the money supply in the financial system. On the other hand, with regard to Islamic monetary instruments, the profit sharing ratio could be used. Islamic banks will buy and sell Islamic securities through

IJIEF: International Journal of Islamic Economics and Finance, 3(1), 121-142 | 122 
Ponziani \& Mariyanti | Islamic Banks and Monetary Policy: The Case of Indonesia

the auction system. In this way, Bank Indonesia can calibrate the money circulating in the banking system before it affects the real economy.

In the field of monetary policy, research has been conducted using Indonesian samples. Sukmana and Ascarya (2010) examined the role of Islamic stock markets in transmitting monetary policy. Ascarya (2012, 2014), Herianingrum and Syapriatama (2016), Setiawan and Karsinah (2016), Widodo (2017) and Fikri (2018) investigated the transmission process through both conventional and Islamic banking, while Zulkhibri and Sukmana (2017) and Octaviani and Arif (2018) examined the transmission process through Islamic banks, specifically passing through their financing. This paper aims to fill the gap by focusing solely on the role of Islamic banks in Indonesia in the monetary transmission process. It therefore differs from the studies of Ascarya (2012, 2014), Herianingrum and Syapriatama (2016), Setiawan and Karsinah (2016), Widodo (2017) and Fikri (2018), which analyzed both conventional and Islamic bank samples. Zulkhibri and Sukmana (2017) employed panel regression analysis, while this paper uses time-series econometrics, i.e Autoregressive Distributed Lag (ARDL), with additional analysis using Granger Causality. Octaviani and Arif (2018) also employed time-series econometrics on Indonesian Islamic bank samples. However, Islamic bank financing is the only balance sheet item analyzed by them This paper will analyze the role of Islamic bank deposits and financing in the monetary transmission process of the bank lending (financing) channel.

\subsection{Objective}

This research uses Islamic banks as the main sample to investigate the bank financing channel in the monetary policy transmission mechanism. Both the financing and deposits of Islamic banks will be further analyzed for their role in monetary transmission as Indonesia operates a dual banking system, with both conventional and Islamic banking comprising its financial system. The central bank focuses its attention on how these two systems react when it applies a new policy. The primary objective of the Indonesian central bank is price stability. Various other objectives are considered paramount to achieving this, i.e. the employment rate, exchange rate stability, and sustainable economic growth. To achieve price stability, the central bank needs to observe the economic situation. In times of a booming economy, it will try to control the money supply so that economy does not overheat, which is known as tight money policy. Through open market operations, the central bank will issue banknotes to reduce money supply in the economy. It can also increase the required reserve requirement so that banks have to maintain increased amounts of reserves within the central bank. These actions will increase the cost of funds available to debtors. As a result, 
Ponziani \& Mariyanti | Islamic Banks and Monetary Policy: The Case of Indonesia

aggregate spending will decrease and acceleration of economic growth will be slowed. On the other hand, in times of economic slowdown, the central bank will make money supply available in the economy through generous purchase of notes or lower reserve requirements. An increase in money supply will energize the economy. In conducting its monetary policy, the central bank needs to put banks into account. Its policies will affect banks' balance sheets through their deposits and loans. In turn, these deposits and loans will affect the economy. It is therefore interesting to consider how Islamic bank financing and deposits will react to monetary policy. This paper further investigates how Islamic banks function in transmitting monetary policy to the economy. The paper comprises five sections. The first is the introduction, followed by the literature review. The methodology is discussed in the third section; the results and analysis in section four; and the final section presents the conclusion and recommendations.

\section{Literature Review}

\subsection{Background Theory}

The importance of monetary policy cannot be overstated. Economic output in terms of goods and services can be influenced by the availability of money supply in the short-run (Akinsola \& Odhiambo, 2017). Increasing money supply will enable real sectors to obtain the financing needed to acquire production factors, which in turn enables them to produce goods and services. Monetary policy is therefore designed to achieve certain inflation targets by paying close attention to economic growth (Dimitrijevic \& Lovre, 2013; Walsh, 2017). Akalpler and Duhok (2017) consider monetary policy to be the most prominent influential factor, having a significant impact on economic growth. One desired characteristic of monetary policy is its countercyclical nature (Twinoburyo \& Odhiambo, 2017). In times of recession, aggregate demands will fall because of the lack of spending by customers, the decrease in investment by firms, or a halt to foreign direct investment inflows. Monetary policy can lessen the consequences of recession by increasing money supply and subsequently triggering growth. However, imprudent monetary policy can also cause a worrying rise in the price of goods and services (Taylor, 2018). As monetary policy increases the supply of money, input prices will rise as the economy approaches full capacity. Therefore, expansion of the money supply should be followed by tight monetary policy to curb price increases. Consequently, the stability target of the price of goods and services is usually accompanied by a focus on macroeconomic indicators, such as output and employment. However, to overcome crisis and spur growth, monetary policy is not the only option. Fiscal policy can also be used 
Ponziani \& Mariyanti | Islamic Banks and Monetary Policy: The Case of Indonesia

for such objectives. This comes in the form of tax management and government spending. Unfortunately, the implementation of fiscal policy requires more time, since approval is required from legislative and executive bodies. Therefore, the formulation and implementation of fiscal policy will have to go through administrative and political processes. Based on this, monetary policy is considered to be of paramount importance to weather difficult economic times and downturns (Kallianiotis, 2015). It is implemented by using financial instruments, which comprise marketable securities issued by the central bank or by market players, including the government. These bear interest or margin/profit and can be used to inject liquidity into or absorb liquidity from the banking system. Besides financial instruments, the central bank also offers a standing facility in the form of deposits and financing. This can also be used to inject liquidity or absorb it from the banking system. Monetary policy through financial instruments or the standing facility will affect the supply of money in the economy. Financing and deposits will be affected by the monetary policy taken by the central bank. In turn, they will influence economic productivity and ultimately have an effect on the level of inflation. The financial instruments and standing facility can be of two types: conventional or Islamic. The conventional bear and earn interest, while the Islamic offer profit-sharing schemes. Monetary policy through Islamic instruments and facilities is expected to be more stable, as it is more closely tied to the real sector through profit-sharing agreements than to the financial sector. As a consequence, financial and economic stability can be created from Islamic instruments and facilities (Wisandani, Iswati, \& Ismal, 2017).

\subsection{Previous Studies}

Many empirical studies have investigated how Islamic banks can act as a transmission channel of central bank monetary policy. Whenever the central bank exercises such policy through Islamic monetary instruments, Islamic bank balance sheets will be affected, with deposits and financing reacting in line with this. Hence, the effect of monetary policy is transmitted to the economy. Discount rates are the variable that represents central bank monetary policy and the impact of monetary policy will be shown in the Manufacturing Index. The preferred methodologies to capture the act of transmission by Islamic banks are Auto-Regressive Distributed Lag (ARDL), Vector Autoregression (VAR), the Vector Error Correction Model (VECM), and the Error Correction Model (ECM). Whenever there is a long-term association, $A R D L, E C M$ and VECM are frequently used to capture the association; i.e., the cointegrating relationship. VAR is used when a cointegrating relationship is not present.

IJIEF: International Journal of Islamic Economics and Finance, 3(1), 121-142 | 125 
Ponziani \& Mariyanti | Islamic Banks and Monetary Policy: The Case of Indonesia

Said and Ismail (2007) investigated how monetary policy has an impact on Islamic bank lending in Malaysia. Their samples consisted of full-flag Islamic bank and Islamic windows. Employing the M3 money supply measure, threemonth Islamic interbank bank rate, and unemployment as the monetary policy indicators, they found that M3 money supply and unemployment affected bank lending. They used the generalized least squares (GLS) method to investigate the relationship. Also using a Malaysian bank sample, Kassim and Majid (2008) examined how Islamic bank loans and deposits reacted to monetary policy changes. Interestingly, they used two approaches in their methodology. ARDL was employed to specially investigate the short-run relationship, while VECM was used to examine the dynamics of both shortand long-run relationships. They found that in the short run, both loans and deposits were affected by monetary policy, while in the long-run, only deposits were affected. The Cumulative Sum of Squares of Recursive residuals (CUSUM) test employed proved that there was no structural break in their models. Kassim, Majid, and Yusof (2009) took the investigation further by including conventional banks as the counterpart of Islamic ones. They were interested in comparing how Islamic and conventional banks reacted to monetary policy and found that Islamic banks were more vulnerable to monetary policy changes, specifically interest rate changes, compared to conventional banks. They attributed the results to the long existence of conventional banks, which has allowed them to anticipate liquidity volatility by using the global linkages they possess. Islamic banks still have underdeveloped links with the market, which leaves them vulnerable to monetary policy changes. An international comparison was made by Yusof, Wosabi, and Majid (2009). Taking samples from Malaysian and Bahraini Islamic banks, they found that Bahraini Islamic bank deposits were more sensitive to monetary policy in the long run, while Malaysian Islamic bank deposits were able to weather the destabilizing effect of monetary policy and hence were more policy invariant. A cointegrating relationship among Islamic bank deposits and monetary policy variables was also found by Sukmana and Kassim (2010). This finding showed the long-run relationship between the discount rate, as a representation of monetary policy, and Islamic bank deposits. Sukmana and Ascarya (2010) investigated monetary transmission through the equity market. They found that the Islamic equity market did not transmit central bank monetary policy. Hence, the equity market could not yet support the real economy. Ascarya (2012) used an Indonesian sample to examine the role of Islamic banks in monetary policy transmission. Using conventional and Islamic bank data, he found that conventional banks did indeed have an important transmission function, but Islamic banks did not. However, Islamic instruments that adopted profit-loss sharing (PLS) positively influenced the aggregate output of the real sector and did not affect inflation. There was also a sign of speculative behavior from the conventional bank data, something

IJIEF: International Journal of Islamic Economics and Finance, 3(1), 121-142 | 126 
Ponziani \& Mariyanti | Islamic Banks and Monetary Policy: The Case of Indonesia

that Islamic banks did not seem to show. Zaheer et al. (2013) found that small banks in Pakistan experienced sharp drops in lending following a monetary policy shock. However, large banks managed to maintain a stable lending position which was indifferent to such shocks. This provides evidence of how Islamic banks are unable to function effectively as instruments for transmitting monetary policy. Therefore, as Islamic banks grow in importance, it is expected that they will be relatively unable to transmit policy from the central bank. Ascarya (2014) found evidence of decoupling between the real sector and financial market and that a financial system based on interest has the inclination to trigger inflation and stifle growth. A financial system based on Islamic precepts only makes a minor contribution to inflation and has no impact on economic growth. The research findings of Ascarya (2014) are shared by Setiawan and Karsinah (2016) and Widodo (2017). The only difference is that Setiawan and Karsinah (2016) argue that Islamic banks do contribute to economic growth. Consistent with Ascarya (2012), Herianingrum and Syapriatama (2016) found that Islamic instruments show potential growth and are able to contain inflation. However, they differ in terms of the influence Islamic banks have on the real sector. Herianingrum and Syapriatama (2016), using IRF and VDA, proved that Islamic banks play a role in transmitting monetary policy and positively influence economic growth. This was corroborated by Octaviani and Arif (2018), who found a positive impact of Islamic bank financing on economic growth. Zulkhibri and Sukmana (2017) employed the panel multiple regression technique to investigate whether macroeconomic monetary policy factors and financing rates influence Islamic banks. They found that financing rates negatively influence Islamic banks, while bank-specific properties have a positive influence. Nevertheless, bank financing was not significantly influenced by monetary policy. This suggests that Islamic banks have not been proven to function as transmitters of monetary policy. This is in line with with Fikri (2018), who demonstrated that Islamic banks are not efficient transmitters, unlike their conventional counterparts. Rafay and Farid (2019) investigated the role of Islamic banks in monetary transmission in Pakistan. They found that Islamic banks play an active role in transmitting monetary policy from the central bank, especially through the lending channel. In addition, besides the shariah motive, profit maximization is an underpinning factor for bank customers. In this case, there is no significant difference between conventional bank customers than those of Islamic banks. In addition, the research showed further evidence of commercial risk. This strengthened previous research that found a pronounced existence of commercial risk in the dual banking system. 


\section{Methodology}

\subsection{Data}

Table 1. Research Variables

\begin{tabular}{llcl}
\hline \multicolumn{1}{c}{ Variable } & \multicolumn{1}{c}{ Description } & Abbreviation & \multicolumn{1}{c}{ Source } \\
\hline Monetary Policy & $\begin{array}{l}\text { Islamic Interbank Overnight } \\
\text { Rate }\end{array}$ & IIOR & Bank Indonesia \\
Financing & Islamic Bank Financing & IFin & Financial Services \\
Deposits & Islamic Bank Deposits & IDep & Authority (OJK) \\
& Financial Services \\
Macroeconomy & Industrial Production Index & IPI & Authority (OJK) \\
Macroeconomy & Inflation & INF & Bank Indonesia \\
\hline
\end{tabular}

This study uses the Islamic overnight rate to represent the monetary policy of the central bank of Indonesia. The ultimate objective of Bank Indonesia is to ensure price stability in the economy. To achieve this, interest rate control is the standard parameter. Therefore, the Islamic overnight interest rate is suitable for depicting the monetary policy of Bank Indonesia. The other variables used are Islamic bank deposits, Islamic bank financing, the Industrial Production Index, and inflation. Deposits and financing will capture the response of Islamic banks to monetary policy, while the Industrial Production Index will measure aggregate productivity and economic growth. Islamic bank deposits and financing will be in natural logarithmic terms. The sample uses monthly data from January 2010 to September 2019. A summary of the variables is given below.

\subsection{Model Development}

Mishkin (1996) first proposed monetary policy transmission through the bank lending channel. Interest rates are the main instrument for central banks to achieve their main objective, price stability. Ascarya (2014) and Fikri (2018) investigated monetary policy transmission in a dual banking system. Their samples included both conventional and Islamic banking systems. This research will modify the research model of Ascarya (2014) and Fikri (2018) to include only Islamic banks in Indonesia. The central bank of Indonesia, Bank Indonesia, will target the Islamic interbank overnight rate (IIOR) as the instrument to transmit monetary policy. Variance in this rate will influence Islamic bank deposits; as deposits mean the availability of funds for financing, this will later affect financing, which can have an effect on aggregate productivity in the economy. The level of productivity will ultimately determine the aggregate level of prices. For instance, when the central bank 
Ponziani \& Mariyanti | Islamic Banks and Monetary Policy: The Case of Indonesia

targets an increase in the rate, the flow when the policy rate increases becomes:

Policy Rate $\uparrow \rightarrow$ IIOR $\uparrow \rightarrow$ IDep $\downarrow \rightarrow$ IFin $\downarrow \rightarrow$ Output $\downarrow \rightarrow$ Prices $\downarrow$

Therefore, the research model is:

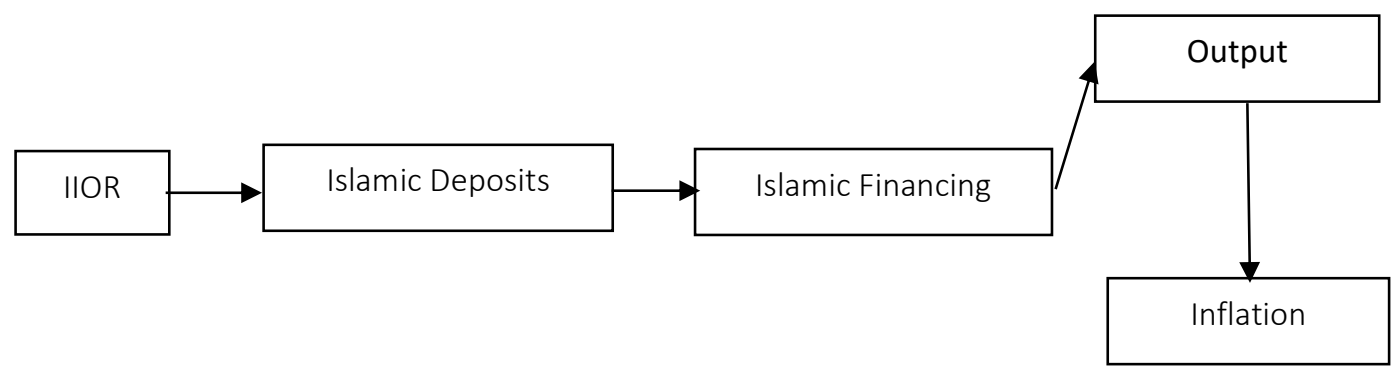

Figure 1. Research Model

\subsection{Method}

\subsubsection{Granger Causality}

Granger causality was first employed to obtain preliminary evidence of the cause and effect relationship between two existing variables. Granger causality can also help define the direction of a relationship or causality when a certain causal relationship is indeterminately known. A time series variable that consistently predicts changes in another variable is the focus of Granger causality (Studenmund, 2017). Technically, a variable is said to Granger cause another variable if its past lagged values or current value influence the other variable (Asutay \& Ergec, 2013). Using this method, researchers can establish whether there exists unidirectional causality, bilateral causality, or independence (Gujarati, 2016). The Granger causality models are:

$$
\begin{aligned}
& A_{t}=\lambda_{1}+\sum_{i=1}^{s} \alpha_{i} A_{t-i}+\sum_{\mathrm{i}=1}^{s} \beta_{i} D_{t-i} \\
& D_{t}=\lambda_{2}+\sum_{i=1}^{s} \delta_{i} D_{t-i}+\sum_{j=1}^{s} \Phi_{i} A_{t-i}
\end{aligned}
$$

The Granger causality test will always involve two equations, one for each variable. If both equations have a significant $F$ value, then bilateral causality exists. One significant $F$ value indicates unidirectional causality. 
Ponziani \& Mariyanti | Islamic Banks and Monetary Policy: The Case of Indonesia

\subsubsection{Autoregressive Distributed Lag Model (ARDL)}

ARDL was employed to examine monetary transmission by Islamic banks. This can model short- and long-term relationships between variables by including a cointegrating relationship (Brooks, 2014). To test for such a relationship, an ARDL-bound test was conducted (Pesaran \& Shin, 1997). The model to test for cointegration is:

Output: $\triangle I P I=\alpha_{1}+B_{1} I P I_{t-1}+B_{2} I I O R_{t-1}+B_{3} I D e p_{t-1}+B_{4} I F i n_{t-1}+\sum_{i=1}^{p} \theta_{1 i} \Delta I P I_{t-i}+$ $\sum_{i=1}^{q} \theta_{2 i} \Delta I I O R_{t-i}+\sum_{i=1}^{r} \theta_{3 i} \Delta I D e p_{t-i}+\sum_{i=1}^{S} \theta_{4 i} \Delta I F i n_{t-i}+e_{1}$

Inflation: $\Delta I N F=\alpha_{1}+B_{1} I N F_{t-1}+B_{2} I I O R_{t-1}+B_{3} I D e p_{t-1}+B_{4} I F i n_{t-1}+\sum_{i=1}^{p} \theta_{1 i} \Delta I N F_{t-i}+$ $\sum_{i=1}^{q} \theta_{2 i} \Delta I I O R_{t-i}+\sum_{i=1}^{r} \theta_{3 i} \Delta I D e p_{t-i}+\sum_{i=1}^{S} \theta_{4 i} \Delta I F i n_{t-i}+e_{2}$

$H_{0}: B_{1}=B_{2}=B_{3}=0$

$H_{1}: B_{1} \neq B_{2} \neq B_{3} \neq 0$

A cointegrating relationship exists whenever $B_{1} \neq B_{2} \neq B_{3} \neq 0$.

After performing the bound test, we proceeded by estimating the short- and long-run relationships. The ARDL model for estimating short-run and long-run relationship (Pesaran and Shin, 1997) is:

Output: $\Delta I P I=\alpha_{1}+\sum_{i=1}^{p} \beta_{1 i} \Delta I P I_{t-i}+\sum_{i=1}^{q} \beta_{2 i} \Delta I I O R_{t-i}+\sum_{i=1}^{r} \beta_{3 i} \Delta I D e p_{t-i}+\sum_{i=1}^{S} \beta_{4 i}$ IFin $_{t-i}$ $+\lambda_{1} E C T_{1}+e_{1}$

Inflation: $\Delta I N F=\alpha_{1}+\sum_{i=1}^{p} \beta_{1 i} \Delta I N F_{t-i}+\sum_{i=1}^{q} \beta_{2 i} \Delta I I O R_{t-i}+\sum_{i=1}^{r} \beta_{3 i} \Delta I D e p_{t-i}+$ $\sum_{i=1}^{S} \beta_{4 i}$ IFin $_{t-i}+\lambda_{2} E C T_{2}+e_{2}$

Where: .ECT $1=|P|_{t-1}-\vartheta X_{t-1}$ $E C T_{2}=I N F_{t-1}-\vartheta X_{t-1}$

The variable $X_{t-1}$ will consist of $\| O R_{t-1}, I D E P_{t-1}$, and IFIN $N_{t-1}$.

$\lambda_{1}$ and $\lambda_{2}$ denote speed adjustment parameter with a negative sign, while $E C T_{1}$ and $E C T_{2}$ are error correction terms. The terms $\beta_{1 i}, \beta_{2 i}, \beta_{3 i}$ are the short-run dynamics of the model, while $\lambda_{1}$ and $\lambda_{2}$ signify the long-run equilibrium adjustment in the form of an error-correction term. 


\section{Results and Analysis}

\subsection{Results}

\subsubsection{Volatility}

Figure 2 shows the movement of each variable during the research period. Graphing their volatility will give an impression of their movement and stationarity.
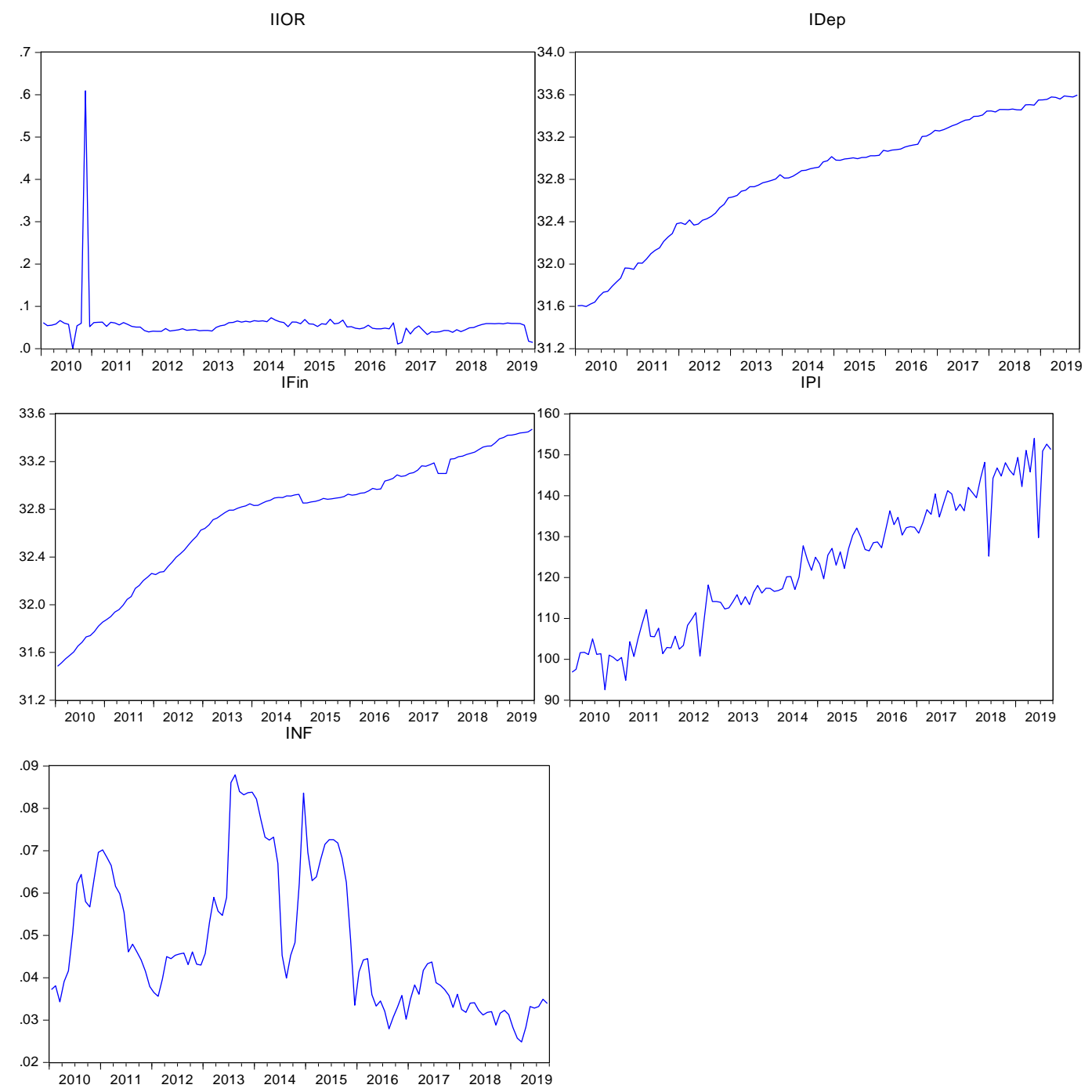

Figure 2. Fluctuations of the Variables

IIOR shows stable movement. In the mid-2010, there was a sharp spike, which indicates tight monetary policy. This sudden increase means a greater return on Islamic interbank money market, which can drain liquidity from the economy. However, during the rest of the period, no sharp increases or decreases occur in the IIOR movement, only ones of insignificant magnitude. IDep increases steadily over time, with no sudden spike in its movement. IFin 
Ponziani \& Mariyanti | Islamic Banks and Monetary Policy: The Case of Indonesia

also shows a steady increase during the research period. In the early months of 2014 and in late 2017, IFin experienced falls, but recovered quickly afterwards. IPI is very volatile, although it displays an increasing trend. Ups will almost certainly be followed by downs. In late 2017 and at the beginning of 2019, it experienced somewhat larger falls and almost every year it has some sudden increases, although the magnitude if these is relatively small. It is clear that IPI is not stationary due to its volatility. INF exhibits erratic volatility, with no certain trends. During 2010 and 2011, 2013 and 2014, and 2014 to mid-2015, there were huge swings in inflation; sharp increases were accompanied by sharp decreases. Post 2015 , the volatility decreased, and was less severe than before. It is also clear that there is no stationarity in INF.

\subsubsection{Descriptive Statistics}

IIOR has a maximum value of 0.0609 . During the research period, the profit sharing ratio offerred by the Islamic interbank market reached a maximum ratio of $7.30 \%$ and a minimum of $1.08 \%$. The mean of $I I O R$ is less than the median, and the IIOR data is skewed to the left. IDep has a maximum value of 32.82918. Since this is a log natural value, we have to apply an antilog exponential, which translates the value to around Rp389 trillion. The minimum value is 31.48414 , which is around Rp47 trillion. This was the value of IDep in the early period when Islamic banking was still in its infancy. IFin has maximum and minimum translated values of Rp.471 trillion and Rp343 trillion respectively. The mean is less than the median, which means that the data are skewed to the left. IPI is skewed to the right, as indicated by a higher mean than median, while INF is skewed to the right. The highest rate of inflation during research period was $8.79 \%$ and the lowest $2.48 \%$; the mean of inflation was $4.8595 \%$.

Table 2 shows the descriptive statistics of the data:

Table 2. Descriptive Statistics

\begin{tabular}{lccrrrr}
\hline Variable & Observations & Mean & Median & Maximum & Minimum & Std. Dev. \\
\hline IIOR & 117 & 0.052268 & 0.054 & 0.073 & 0.0108 & 0.011263 \\
IDep & 117 & 32.82918 & 32.97643 & 33.59666 & 31.59774 & 0.571698 \\
IFin & 117 & 32.73246 & 32.88454 & 33.47127 & 31.48414 & 0.525711 \\
IPI & 117 & 122.5921 & 122.2119 & 154.02 & 92.55 & 15.93944 \\
INF & 117 & 0.048595 & 0.0442 & 0.0879 & 0.0248 & 0.016725
\end{tabular}


Ponziani \& Mariyanti | Islamic Banks and Monetary Policy: The Case of Indonesia

\subsubsection{Unit Root Test}

Table 3 shows the stationarity check for the variables:

Table 3. Unit Root Test

\begin{tabular}{lllll} 
& \multicolumn{2}{c}{ Level } & \multicolumn{2}{c}{$1^{\text {st }}$ Difference } \\
\hline & ADF & PP & \multicolumn{1}{l}{ ADF } & PP \\
IIOR & 0.0000 & 0.0000 & 0.0000 & 0.0001 \\
INF & 0.1135 & 0.2392 & 0.0000 & 0.0000 \\
IPI & 0.9854 & 0.6287 & 0.0000 & 0.0001 \\
IDep & 0.2353 & 0.0024 & 0.568 & 0.0000 \\
IFin & 0.0002 & 0.0006 & 0.0000 & 0.0000 \\
\hline
\end{tabular}

The first procedure was the stationarity test. This was of paramount importance because we wanted to avoid spurious regression. The methods chosen were the augmented Dickey-Fuller (ADF) and Phillips-Perron (PP) tests.

IIOR and Ifin are stationary at level, while INF and IPI are not, although they are stationary at first difference. An interesting case occurs with IDep. At level, ADF rejects its stationarity, while PP supports it. When first-differenced, ADF still rejects the stationarity, while PP continues to support it. Hence, we cannot employ the vector autoregressive (VAR), vector-error correction (VECM) or error-correction(ECM) models. Therefore, these different types of stationarity do not allow for the inclusion of a long-term relationship. However, the contrasting stationarity conditions of the research variable support the use of the ARDL model.

\subsubsection{Results of Granger Causality}

The results of the Granger causality test are shown in Table 4.

Table 4. Granger Causality Results

\begin{tabular}{lcccccc}
\hline & \multicolumn{5}{c}{ Dependent Variables } \\
\hline & & IIOR & IDep & IFin & IPI & INF \\
\hline \multirow{3}{*}{ Independent } & IIOR & - & $7.65^{*}$ & $2.42^{* * *}$ & 0.04 & 0.29 \\
Variables & IDep & $4.097^{* *}$ & - & 0.15 & $5.98^{*}$ & 0.28 \\
& IFin & 1.379 & 15.23 & - & $3.32^{* *}$ & 0.26 \\
& IPI & $2.65^{* * *}$ & $1.91^{* *}$ & 0.02 & - & $3.18^{* * *}$ \\
& INF & $4.99^{*}$ & 0.13 & $4.00^{* *}$ & 0.12 & - \\
\hline
\end{tabular}

*significant at $1 \%$ level.

**significant at $5 \%$ level.

$* * *$ significant at $10 \%$ level. 


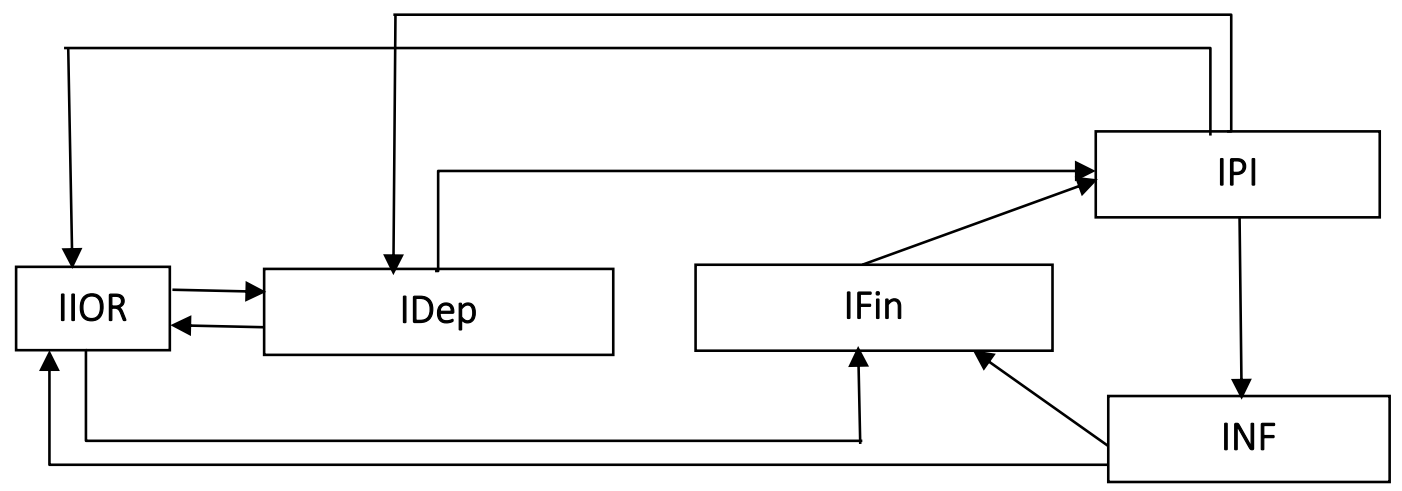

Figure 3. Granger Causality Relationships

According to Figure 3, bivariate causality exists between IDep and IIOR and between IDep and IPI. Univariate causality exists between IIOR and IFin, IFI and IPI, IPI and IIOR, IPI and INF, INF and IIOR, and INF and IFin. All other connections besides those mentioned previously are independent. Independence indicates two possibilities, that there is either no causality relationship or no long-term cointegrating relationship. The figure maps the causality relationships revealed by Granger causality.

\subsubsection{Results of ARDL}

Table 5 shows the results of the bound test for cointegration for the dependent variable IPI.

The table shows that there is cointegrating relationship when IPI is the dependent variable. The $p$-value for the cointegrating variable is below 0.1 , which indicates that $H_{1}: b_{1} \neq b_{2} \neq B_{3} \neq 0$, in Pesaran and Shin (1997). Hence, this proves that there is a long-term relationship in the ARDL model for IPI.

Table 5. Bound test for cointegration for IPI

\begin{tabular}{lrrrl}
\hline Variable & Coefficient & \multicolumn{1}{l}{ Std. Error } & \multicolumn{1}{c}{ t-Statistic } & Prob. \\
\hline $\mathrm{D}(\mathrm{IPI}(-1))$ & -0.6231 & 0.133531 & -4.66634 & 0.0000 \\
$\mathrm{D}(\mathrm{IPI}(-2))$ & -0.44134 & 0.12689 & -3.47815 & 0.0007 \\
$\mathrm{D}(\mathrm{IPI}(-3))$ & -0.27325 & 0.105347 & -2.59382 & 0.0108 \\
$\mathrm{D}(\mathrm{IDEP})$ & 6.293451 & 9.131073 & 0.689235 & 0.4922 \\
$\mathrm{D}(\mathrm{IFIN})$ & -0.08514 & 7.590498 & -0.01122 & 0.9911 \\
$\mathrm{D}($ IIOR) & -8.13247 & 39.762 & -0.20453 & 0.8383 \\
CointEq(-1) & -0.21915 & 0.121371 & -1.8056 & 0.0738 \\
\hline
\end{tabular}

The results of the bound test for cointegration for the dependent variable INF are shown in Table 6. 
Ponziani \& Mariyanti | Islamic Banks and Monetary Policy: The Case of Indonesia

Table 6. Bound test for cointegration for IPI

\begin{tabular}{lrrrc}
\hline \multicolumn{1}{c}{ Variable } & Coefficient & Std. Error & t-Statistic & Prob. \\
\hline $\mathrm{D}($ INF) & -0.18172 & 0.093415 & -1.94529 & 0.0544 \\
$\mathrm{D}(\mathrm{IDEP})$ & -0.01754 & 0.007985 & -2.19656 & 0.0302 \\
$\mathrm{D}(\mathrm{IFIN})$ & 0.016858 & 0.008556 & 1.970375 & 0.0514 \\
$\mathrm{D}(\mathrm{IIOR})$ & -0.0509 & 0.053037 & -0.95975 & 0.3393 \\
CointEq(-1) & -0.10788 & 0.043315 & -2.49046 & 0.0143 \\
\hline
\end{tabular}

In Table 6, cointegration has a p-value of 0.0143 , well below 0.05. A long-term relationship therefore exists in the ARDL model for INF.

Table 7 shows the ARDL estimation for IPI and includes the error correction term. The lag length for the regressors is 4 ; the criterion for choosing this length is based on the Schwartz Information Criterion.

As suggested by Table 7, the short-term variables that influence IPI are IDep lag 2 and 3, IPI lag 2 and 3, and the error-correction term. There exist longand short-term dynamics in the model. The error-correction term is of the correct sign (minus), with a coefficient of -0.697343 . This means $0.697343 \%$ of the deviation in IPI will be corrected each month, which is a very slow adjustment process. However, this should not be surprising given the small proportion of Islamic banks in Indonesia.

Table 7. ARDL Estimation for IPI

\begin{tabular}{crrrr}
\hline Variable & Coefficient & Std. Error & t-Statistic & Prob. \\
\hline C & 1.496169 & 0.772004 & 1.938031 & 0.0556 \\
D(IPI(-1)) & -0.271652 & 0.219546 & -1.237338 & 0.2190 \\
D(IDEP(-1)) & 27.82633 & 22.04652 & 1.262164 & 0.2100 \\
D(IFIN(-1)) & 10.59097 & 20.77490 & 0.509796 & 0.6114 \\
D(IIOR(-1)) & -17.26175 & 53.64329 & -0.321788 & 0.7483 \\
D(IPI(-2)) & -0.440725 & 0.143386 & -3.073693 & 0.0028 \\
D(IDEP(-2)) & -48.60618 & 20.23226 & -2.402410 & 0.0183 \\
D(IFIN(-2)) & 25.77296 & 20.82855 & 1.237386 & 0.2190 \\
D(IIOR(-2)) & 38.86692 & 62.72640 & 0.619626 & 0.5370 \\
D(IPI(-3)) & -0.337965 & 0.134541 & -2.511978 & 0.0137 \\
D(IDEP(-3)) & -67.60912 & 20.60492 & -3.281212 & 0.0015 \\
D(IFIN(-3)) & 19.08086 & 21.32566 & 0.894737 & 0.3732 \\
D(IIOR(-3)) & 6.961210 & 63.05235 & 0.110404 & 0.9123 \\
D(IPI(-4)) & -0.077556 & 0.110429 & -0.702314 & 0.4842 \\
D(IDEP(-4)) & -35.05207 & 22.09070 & -1.586734 & 0.1159 \\
D(IFIN(-4)) & 30.22429 & 21.13519 & 1.430046 & 0.1560 \\
D(IIOR(-4)) & -34.21411 & 59.87245 & -0.571450 & 0.5691 \\
ErrorCorrect(-1) & -0.697343 & 0.228566 & -3.050953 & 0.0030 \\
\hline
\end{tabular}


Ponziani \& Mariyanti | Islamic Banks and Monetary Policy: The Case of Indonesia

Table 8. ARDL Estimation for INF

\begin{tabular}{lrrrr}
\hline \multicolumn{1}{c}{ Variable } & Coefficient & Std. Error & t-Statistic & Prob. \\
\hline C & 0.001303 & 0.000962 & 1.355396 & 0.1784 \\
$D(I N F(-1))$ & 1.753335 & 0.388886 & 4.508614 & 0.0000 \\
$D(I D E P(-1))$ & -0.00679 & 0.025519 & -0.26598 & 0.7908 \\
$D(I F I N(-1))$ & -0.00966 & 0.026013 & -0.37145 & 0.7111 \\
$D(I I O R(-1))$ & 0.04423 & 0.068693 & 0.643872 & 0.5211 \\
$D(I N F(-2))$ & -0.17327 & 0.10212 & -1.69667 & 0.0929 \\
$D(I D E P(-2))$ & 0.025474 & 0.025243 & 1.009143 & 0.3154 \\
$D(I F I N(-2))$ & -0.03523 & 0.027916 & -1.26208 & 0.2099 \\
$D(I I O R(-2))$ & 0.046821 & 0.078974 & 0.592864 & 0.5546 \\
$D(I N F(-3))$ & 0.058163 & 0.097639 & 0.595695 & 0.5527 \\
$D(I D E P(-3))$ & -0.02504 & 0.024963 & -1.00323 & 0.3182 \\
D(IFIN(-3)) & -0.02074 & 0.028111 & -0.73783 & 0.4624 \\
D(IIOR(-3)) & 0.007771 & 0.074142 & 0.104816 & 0.9167 \\
ErrorCorrect(-1) & -1.52014 & 0.409503 & -3.71216 & 0.0003 \\
\hline
\end{tabular}

Table 8 shows the ARDL estimation for INF. As for IPI, the estimation includes the error correction term. The lag length for the regressors is 3 , based on the Schwartz Information Criterion.

In Table 8, it can be seen that the autoregressive components of INF influence INF. Hence, INF lag 1 and 2 have a significant influence on INF. The last row contains the test results for the error-correction term, which are significant with a coefficient of 1.52014. The sign is correct (minus), meaning that any deviation in INF will be corrected at an adjustment speed of $1.52014 \%$ per month. This indicates that it would take roughly 16 months to fully correct the deviation.

\subsection{Analysis}

Granger causality indicates that there exists bivariate causality between IIOR and IDep; any movement in IIOR will induce volatility in IDep. The reverse also applies - any change in IDep will trigger movement in IIOR. Ascarya (2014) and Fikri (2018) revealed the univariate causality from IDep to IIOR, which is an indication of how IIOR takes into account deposits in Islamic banks. The higher the IDep, the lower the level of liquidity in the economy, because money supply decreases. This will lead to economic stagnation. IIOR will deflate to supply the economy, with more liquidity taken from the Islamic banking system. Furthermore, any increase in IIOR will positively affect IDep. IIOR represents the rate of return. Any increase in this will attract depositors to save their money for greater returns, so deposits in Islamic banks will increase. IIOR has univariate causality with IFin; any movement in IIOR will be followed 
Ponziani \& Mariyanti | Islamic Banks and Monetary Policy: The Case of Indonesia

by movement in IFin. As a parameter for return, IFin will adjust to the change in IIOR. The adjustment in IFin will first occur in the form of adjusting the profit sharing ratio. This adjustment will lead to a change in the magnitude of total Islamic financing. This contradicts Octaviani and Arief (2018), who found no causality relationship between IIOR and financing. IFin also imposes univariate causality on IPI; any movement in IPI will be preceded by movement in IFin. An increase in IFin means economic parties have more liquidity and access to production factors. They will have more infrastructure at their disposal to increase production. A decrease in IFin will reduce the availability of liquidity to obtain more production factors, resulting in a decrease in production. This result is consistent with those of Herianingrum and Syapriatama (2016) and Fikri (2018). Furthermore, IPI produces movement in INF. An increase in IPI signifies an increase in economic activity; in times when the economy is booming, inflation ensues. When IPI deflates, there is a slowdown in the general increase of the price of goods and services. This result is contrary to Ascarya (2014), who proved otherwise. Movement in INF will trigger movement in IPI. A general rise in the price of goods and services will entice producers to increase production to benefit from the price increases. IPI also has bivariate causality with IDep. An increase in IPI will precede an increase in IDep. When productivity in the economy increases, economic parties, such as the private sector, can gain more from the sale of produced goods and services. Later, liquidity in the banking sector will increase due to the increase in deposits. Due to bivariate causality, movement in IDep will trigger movement in IPI. The ARDL test corroborated this finding and even revealed the negative influence of IDep on IPI for lags 2 and 3. An increase in IDep will lower IPI. IDep represents the availability of liquidity in the economy; when IDep increases, liquidity in the economy will decrease because money supply has been attracted inside the banking system. Lower money supply acts as a disincentive, as producers lack liquidity to obtain production factors. Lower productivity ensues. These results agree with those of Sukmana and Kassim (2010) but not with those of Herianingrum and Syapriatama (2016) or Fikri (2018), who found no short-term relationship causality between IDep and IPI. IPI also has univariate causality with IIOR. This is indicative of how monetary policy also considers the movement of IPI. A sharp increase in IPI can encourage inflation. Consequently, IIOR will be increased to curb the inclination of prices to rise. Conversely, a decrease in IPI results in low productivity, so IIOR will be reduced to stimulate the economy. Movement in INF will be followed by movement in IFin. In times of increasing prices, injection of liquidity is needed to match demand with increased prices. IFin will be volatile to meet the requirement of liquidity. Monetary policy can also stimulate an increase in IFin when there is a slowdown in price increases. This increase in IFin will help the lethargic economy recover. According to Setiawan and Karsinah (2016), IFin and INF have bivariate causality. IFin can also trigger 
Ponziani \& Mariyanti | Islamic Banks and Monetary Policy: The Case of Indonesia

INF when liquidity injection stimulates an increase in the price of goods and services. Finally, consistent with Ascarya (2014) and Setiawan and Karsinah (2016), fluctuation in INF precedes movement in IIOR. This shows how the level of prices becomes the feedback for IIOR assignment. The ARDL test results shows significant error-correction terms for both IPI and INF. The coefficient for IPI is 0.697343 , while that for INF is 1.52014 . Convergence in IPI will be stable in about two months, while it takes 16 months to correct INF. Cointegration in IPI is a new finding. Fikri (2018) found no cointegrating relationship for IPI. However, Fikri (2018) obtained a cointegrating coefficient of 3.2782, comparable to that of this research of 1.52014. However, it is still a low number for the correction of INF by $t$ Islamic banks' deposits and financing.

\section{v. Conclusion and Recommendations}

\subsection{Conclusion}

This paper aimed to examine the role of Islamic banks in transmitting monetary policy. The stationarity test showed that the data were of mixed stationarity. Hence, Granger causality and ARDL were considered suitable methods to analyze the data. Granger causality revealed various causality relationships. The Islamic interbank overnight rate has bivariate causality with Islamic deposits, while Islamic deposits and financing have a univariate relationship with the industrial production index. This index has univariate relationships with inflation, Islamic deposits and the Islamic interbank overnight rate. Finally, inflation has a univariate relationship with the Islamic interbank overnight rate. This shows that the Islamic interbank overnight rate made its way through the industrial production index and inflation through the elements of Islamic deposits and financing. As for the ARDL testing results, Islamic deposits have a significant negative influence on IPI for lags 2 and 3. Cointegration exists for both IPI and inflation. This confirms that Islamic banks contribute in the long-term to the correction of IPI and inflation.

\subsection{Recommendations}

The recommendations based on the results of the study can be summarized as follows. Granger causality shows that any movement in the Islamic interbank overnight rate is expected to trigger fluctuations in Islamic deposits and financing. Hence Islamic deposits and financing are subject to changes in the Islamic interbank overnight rate. Bank Indonesia could modify and alter this rate to determine the amount of liquidity injected into or absorbed by the economy. Second, Islamic bank deposits can contribute to output and growth in the short run. Encouraging greater output or curbing output in fear of 
Ponziani \& Mariyanti | Islamic Banks and Monetary Policy: The Case of Indonesia

economic overheating could be conducted by using the element of Islamic bank deposits. ARDL shows that within 2 or 3 months the influence of Islamic bank deposits will begin to take effect. Third, Islamic bank financing has begun to lose its effectiveness in contributing to output and inflation. The ARDL test only showed a long-term relationship, with no significant short-tem influence of Islamic bank financing on output and inflation. The channel for financing has grown tremendously recently. Creative chanelling through mobile devices by way of applications has eroded bank dominance in financing. Central banks will need to consider how financial technology companies contribute to the economy, in terms of output and inflation. Products that utilize profit-sharing schemes should also be encouraged. This will further the contribution of Islamic bank financing to the economy.

The study has certain limitations. The mixed stationarity of the data prevents the analysis from employing Impulse Response Function (IRF) and Forecast Error Variance Decomposition (FEVD). These two methods can trace the magnitude of variance induced by shocks occuring to the system over time. Further research could use the same type of data stationarity. Further research could also investigate how the monetary policy transmission mechanism operates through rural Islamic banks (BPRS) and the small and medium enterprise index. Since most research on monetary transmission still focuses on large manufacturing indexes and only takes samples of Islamic commercial banks, the role of fintech companies in monetary transmission could also be examined, since they have become a popular form of financing and can reach out to the unbanked population. 
Ponziani \& Mariyanti | Islamic Banks and Monetary Policy: The Case of Indonesia

\section{References}

Akalpler, E., \& Duhok, D. (2018). Does Monetary Policy Affect Economic Growth: Evidence from Malaysia. Journal of Economic and Administrative Sciences, 34(1), 2-20.

Akinsola, F. A., \& Odhiambo, N. M. (2017). Inflation and Economic Growth: A Review of the International Literature. Comparative Economic Research, 20(3), 41-56.

Alaro, A.-R. A., \& Hakeem, M. (2011). Financial Engineering and Financial Stability: The Role of Islamic Financial System. Journal of Islamic Economics, Banking, and Finance, 7(1), 25-38.

Ascarya. (2012). Transmission Channel and Effectiveness of Dual Monetary Policy in Indonesia. Bulletin of Monetary Economics and Banking, 14(3), 269-298.

Ascarya. (2014). Monetary Policy Transmission Mechanism Under Dual Financial System in Indonesia: Interest-Profit Channel. International Journal of Economics, Management and Accounting, 22(1), 1-32.

Asutay, M., \& Ergec, E. H. (2013). Searching for the Nexus between Money, Deposits, and Loans (Financing) in Malaysian and Turkish Islamic and Conventional Banking: A Comparative Analysis (2007-2013). Afro Eurasian Studies, 12(1), 72-90.

Brooks, C. (2014). Introductory Econometrics for Finance. Cambridge: Cambridge University Press.

Dimitrijevic, B., \& Lovre, I. (2013). Essay on Monetary Policy and Economic Growth. Journal of Central Banking Theory and Practice, 2(1), 111138.

Enders, W. (2014). Applied Econometrics Time Series. University of Alabama: Wiley.

Fikri, R. J. (2018). Monetary Transmission Mechanism Under Dual Financial System in Indonesia: Credit-Financing Channel. Journal of Islamic Monetary Economics and Finance, 4(2), 251-278.

Gujarati, D. N. (2016). Basic Econometrics. McGraw-Hill Europe: UK Ed.

Herianingrum, S., \& Syapriatama, I. (2016). Dual Monetary System and Macroeconomic Performance in Indonesia. Al-lqtishad: Jurnal IImu Ekonomi Syariah (Journal of Islamic Economics), 8(1), 65-80.

Kallianiotis, I. N. (2015). Economic Crises and the Substitution of Fiscal Policy by Monetary Policy. International Journal of Economics and Financial Issues, 5(1), 44-68. 
Ponziani \& Mariyanti | Islamic Banks and Monetary Policy: The Case of Indonesia

Kassim, S. H., \& Majid, M. S. (2008). The Role of Bank Lending in the Monetary Transmission Process of a Developing Economy: Evidence from Malaysia. Savings and Development, 4, 301-331.

Kassim, S. H., Majid, M. S., \& Yusof, R. M. (2009). Impact of Monetary Policy Shocks on the Conventional and Islamic Banks in a Dual Banking System: Evidence from Malaysia. Journal of Economic Cooperation and Development, 30(1), 41-58.

Miah, D. M., \& Uddin, H. (2017). Efficiency and Stability: A Comparative Study Between Islamic and Conventional Banks in GCC Countries. Future Business Journal, 3(2), 172-185.

Mishkin, F. S. (1996). The Channels of Monetary Transmission: Lessons for Monetary Policy. Cambridge, Massachusetts: NBER Working Paper No. 5464.

Octaviani, I., \& Arif, M. N. (2018). Islamic Monetary Policy and Its Impact on Real Sector. Trikonomika, 17(2), 43-48.

Pesaran, M., \& Shin, Y. (1998). An Autoregressive Distributed Lag Modelling Approach to Cointegration Analysis. Symposium at the Centennial of Ragnar Frisch. Oslo: The Norwegian Academy of Science and Letters.

Rafay, A., \& Farid, S. (2019). Islamic Banking System: A Credit Channel of Monetary Policy-Evidence from an Emerging Economy. Economic Research, 32(1), 742-754.

Rashid, A., Yousaf, S., \& Khaleequzzaman, M. (2017). Does Islamic Banking Really Strengthen Financial Stability? Empirical Evidence from Pakistan. International Journal of Islamic and Middle Eastern Finance and Management, 10(2), 130-148.

Said, F. F., \& Ismail, A. G. (2007). How Does The Changes in Monetary Policy Affect Lending Behaviour of Islamic Banking in Malaysia? Journal Ekonomi Pembangunan: Kajian Ekonomi Negara Berkembang, 12(3), 163-177.

Setiawan, R. Y., \& Karsinah. (2016). Mekanisme Transmisi Kebijakan Moneter Dalam Mempengaruhi Inflasi dan Pertumbuhan Ekonomi di Indonesia. Economics Development Analysis Journal, 5(4), 460-474.

Studenmund, A. H. (2017). Using Econometrics: A Practical Guide (7th ed.). Harlow: Pearson.

Sukmana, R., \& Ascarya. (2010). The Role of Islamic Stock Market in the Monetary Transmission Process in the Indonesian Economy. Insaniah-IRTI International Conference (pp. 1-18). Langkawi: IRTI.

Sukmana, R., \& Kassim, S. H. (2010). Roles of the Islamic Banks in the Monetary Transmission Process in Malaysia. International Journal of Islamic and Middle-Eastern Finance and Management, 3(1), 7-19. 
Ponziani \& Mariyanti | Islamic Banks and Monetary Policy: The Case of Indonesia

Taylor, J. B. (2019). Inflation Targeting in High Inflation Emerging Economies: Lessons About Rules and Instruments. Journal of Applied Economics, 22(1), 103-116.

Twinoburyo, E. N., \& Odhiambo, N. M. (2018). Monetary Policy and Economic Growth: A Review of International Literature. Journal of Central Banking Theory and Practice, 2, 123-137.

Walsh, C. E. (2017). Monetary Theory and Policy. Massachusetts: Massachusetts Institute of Technology.

Widodo, A. (2017). Evaluating the Effectiveness of Dual Monetary Policy in Promoting Price Stability in Indonesia. Iqtishadia: Jurnal Kajian Ekonomi dan Bisnis Islam, 10(2), 210-233.

Wisandani, I., Iswati, S., \& Ismal, R. (2017). The Monetary Policy in Indonesia: in the Perspective of Islamic Economics. International Journal of Nusantara Islam, 5(1), 59-74.

Yungucu, B., \& Saiti, B. (2016). The Effects of Monetary Policy on the Islamic FInancial Services Industry. Qualitative Research in Financial Markets, 8(3), 218-228.

Yusof, R. M., Wosabi, M. A., \& Majid, M. S. (2009). Monetary Policy Shocks in a Dual Banking System: Empirical Evidence from Malaysia and Bahrain. Journal of Economic Cooperation and Development, 30(2), 126.

Zaheer, S., Ongena, S., \& Wijnbergen, S. J. (2013). The Transmission of Monetary Policy Through Conventional and Islamic Banks. Journal of Central Banking, 9(4), 175-224.

Zulkhibri, M., \& Sukmana, R. (2017). The FInancing Channel and Monetary Policy in a Dual Banking System: Evidence from Islamic Banks in Indonesia. Economic Notes, 46(1), 117-143. 